\title{
Synthesis of Biodiesel by Transesterification of Used Frying Oils (UFO) through Basic Homogeneous Catalysts ( $\mathrm{NaOH}$ and $\mathrm{KOH})$
}

\author{
Hamza Belkhanchi $^{1}$, Mouhcine Rouan ${ }^{2}$, Maryama Hammi ${ }^{3}$, Younes Ziat ${ }^{1}{ }^{1 D}$, Mohammed Chigr ${ }^{2}$ \\ 1 Laboratory of Engineering and Applied Technologies, Higher School of Technology, Sultan Moulay Slimane University, \\ Beni Mellal, Morocco \\ 2 Laboratory of Organic and Analytical Chemistry, Sultan Moulay Slimane University, Faculty of Sciences and Technics, \\ BP 523, 23000, Beni-Mellal, Morocco \\ 3 University of Mohammed V, Laboratory of Materials, Nanotechnologies and Environment, Department of Chemistry, \\ Faculty of Sciences, Avenue Ibn Batouta, P.O.B. 1014, Rabat, Morocco \\ * Correspondence: maryama.hammichimie@gmail.com;
}

Received: 21.12.2020; Revised: 15.01.2021; Accepted: 20.01.2021; Published: 31.01.2021

\begin{abstract}
The quest for an alternative sustainable source without petroleum technology and its refining has prompted the development of biofuels, such as biodiesel, from the transesterification of new or utilized vegetable oil. This work is devoted to the investigation of the transesterification of a used vegetable oil and optimization of the various parameters influencing the synthesis of biodiesel, such as the molar proportion (alcohol/oil), the amount of catalyst added and their weight percentage, the type of alcohol, the temperature $\mathrm{T}\left({ }^{\circ} \mathrm{C}\right)$ and the reaction time. From this standpoint, the current work's significant target is to propel the preliminary conditions of the transesterification response of fatty oils to create biodiesel from utilized vegetable oils. Diverse physicochemical characteristics were investigated (in terms of density, viscosity, acidity index, pour point, and flash point) to obtain biodiesel accordingly with international standards and commercial biodiesel.
\end{abstract}

Keywords: biodiesel; vegetable oil; alkyl esters; flash point; pour point; acidity index; viscosity.

(C) 2021 by the authors. This article is an open-access article distributed under the terms and conditions of the Creative Commons Attribution (CC BY) license (https://creativecommons.org/licenses/by/4.0/).

\section{Introduction}

The manufacture of biodiesel represents an alternative source of fuel production; which is known as renewable [1-4], biodegradable [5,6], sustainable [7], clean and non-toxic [8], the resources are abundantly available [9], neutral in $\mathrm{CO}_{2} / \mathrm{GHG}$ (greenhouse gases) [9-12], they cause negligible or zero SOx emissions [13,14], they provide lower NOx emissions $[15,16]$, environmentally friendly [17,18], can be produced locally [19], they have a high flash point and less pollution [20-22], their production processes and/or biofuel farms are generally safe $[23,24]$.

The applications of biofuels in life have been detailed in numerous publications [2528]. These applications have radically changed and improved the lives of people all over the world, especially in the automotive field where biodiesel can be used both as an alternative to conventional diesel or as an additive, neat or blended [29], it has less amount of pollutants during and after the combustion process. Engine life can be improved thanks to biodiesel viscosity twice as high as petroleum diesel [30], also during the combustion of biodiesel, the reduction of total unburned hydrocarbons is greater than $90 \%$ [31]. Biodiesel is produced by 
converting vegetable oils, animal, or waste origin into alkyl esters [32-38]. The transesterification reaction is one of the most important methods used to convert vegetable oils into diesel fuel due to the process's low cost and simplicity. It is a process in which triglycerides are converted in the presence of an alcohol (methanol or ethanol), an ester, and glycerol catalyst $[39,40]$. To minimize production costs, researchers are currently using leftover cooking oils and other inedible oils as raw materials [41-47].

This work aims to produce a biodiesel meeting the international quality standard, from used frying oil (UFO) by the reaction of transesterification. To achieve the best conversions of UFO, other parameters controlling the reaction of transesterification were studied, such as the molar ratio of alcohol to acid, the amount of catalyst, the time and temperature of the reaction. The biodiesel will be characterized and compared to petrodiesel and commercial biodiesel, which meets the international quality standard.

\section{Materials and Methods}

\subsection{Starting materials.}

The raw materials used to carry out this work are new vegetable oils of different origins (Sunflower, Soybean, Canola). Three types of used vegetable oils (HFU) with a frequency of use not exceeding 4 times.

\subsection{Reagents.}

The different reagents used for our experiments are sodium hydroxide $(\mathrm{NaOH})$, potassium hydroxide $(\mathrm{KOH})$, methanol $\left(\mathrm{CH}_{3} \mathrm{OH}\right)$, ethanol $\left(\mathrm{C}_{2} \mathrm{H}_{5} \mathrm{OH}\right)$, and 2-Propanol $\left(\mathrm{C}_{3} \mathrm{H}_{8} \mathrm{OH}\right)$.

\subsection{Biodiesel production.}

A mixture of used frying oil from different sources (Soybean, Sunflower, Canola) and alcohol (Methanol, Ethanol, 2-Propanol) in the presence of a basic homogeneous catalyst $(\mathrm{NaOH}, \mathrm{KOH})$ undergone continuous stirring at different temperatures (ranging from ambient temperature to $72 \mathrm{C}^{\circ}$ ) in an Erlenmeyer flask. These working parameters can be changed in the manufacturing attempts of biodiesel by the transesterification reaction to optimize this reaction's conditions to increase the yield.

The solution resulting from the reaction is left to stand for the separation of the two phases; the glycerol, which has a greater density than biodiesel, is located at the bottom of the separating funnel after 24 hours of decantation.

The resulting biodiesel is placed in a separating funnel and then slowly rinsed with distilled water to remove the excess alcohol and catalyst. After rinsing biodiesel, it is recovered and dried with $\mathrm{Na}_{2} \mathrm{SO}_{4}$. The obtained product is weighed in order to determine its yield.

The yield of the reaction is calculated according to the following formula:

$$
\eta(\%)=\frac{m_{b}}{m_{h}} * 100
$$

With : $\quad m_{b}$ : weight of biodiesel;

$m_{h}$ : weight of used frying oil;

The global chemical reaction is presented in Figure 1: 


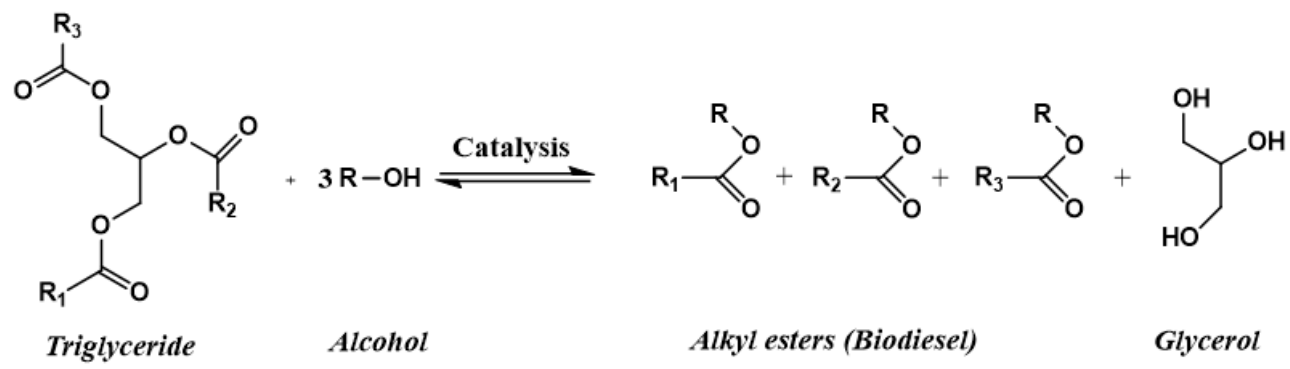

Figure 1. General reaction of the transesterification of triglycerides with alcohol (R-OH) where R1, R2, and R3 are the alkyl groups of fatty acids.

The transesterification reaction is affected by several varied parameters, and its degradation yield is limited by the temperature, the type of catalyst, the quantities, ratios of the used reagents, and the weight percentage of catalyst $(\mathrm{KOH}$ and $\mathrm{NaOH}) / \mathrm{UFO}$. Also, reaction time, type of alcohol, and source of oil are influencing parameters.

\subsection{Physico-chemical characteristics of used frying oils, new oils, and biodiesel.}

The physicochemical properties were determined according to international standards. In our study, we determined density (NFT 60-214), viscosity, acid index (NFT 60-204), open cup flash point (NF EN ISO 2592/01) for oils, a closed-cup flashpoint for biodiesel (ISO 2719/16), pour point (NF T60-105) and color (NF ISO 2049/98).

\section{Results and Discussion}

\subsection{Study of the parameters influencing the transesterification reaction.}

3.1.1. Temperature effect on the yield of biodiesel.

The used frying oil (UFO) transesterification reaction was performed using $1 \mathrm{wt} \% \mathrm{KOH}$ and $\mathrm{MeOH} / \mathrm{UFO}$ molar ratio: 6: 1 . Temperatures of $18,42,54$, and $72{ }^{\circ} \mathrm{C}$ were used for a reaction time of $60 \mathrm{~min}$. Figure 2 exhibits the evolution of biodiesel's yield depending on the temperature of used frying oil from soybean.

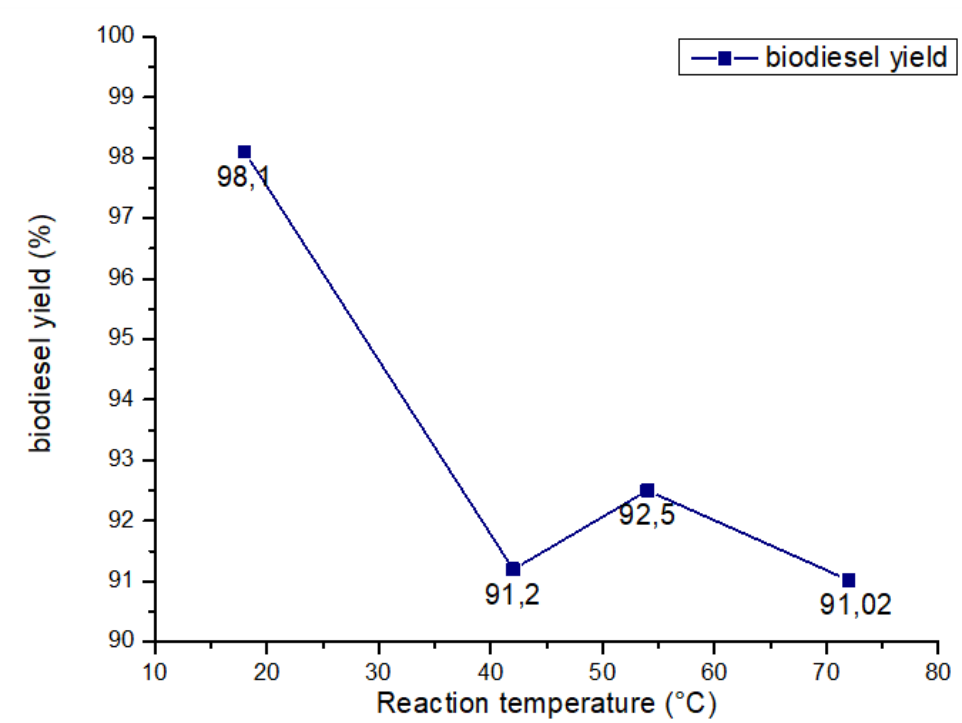

Figure 2. Evolution of biodiesel yield as a function of temperature (KOH: $1 \%$ by weight, $\mathrm{MeOH} / \mathrm{UFO}$ molar ratio: $6: 1,60 \mathrm{~min})$. 
Figure 2 shows that when the transesterification reaction is carried out at different temperatures, the maximum yield of biodiesel of $98 \%$ is obtained at a reaction temperature of $18^{\circ} \mathrm{C}$ (ambient temperature). Therefore, the reaction temperature seems to influence the yield of biodiesel is ambient temperature.

3.1.2. Influence of the reaction time on the yield of biodiesel.

The influence of various transesterification reaction times (10, 30, 60, 90, and $120 \mathrm{~min}$ ) at room temperature $\left(19^{\circ} \mathrm{C}\right)$ was studied (MeOH /UFO) molar ratio of $6: 1$ and $1 \%$ by weight of $\mathrm{KOH})$. Figure 3 shows the evolution of biodiesel yield as a function of reaction time.

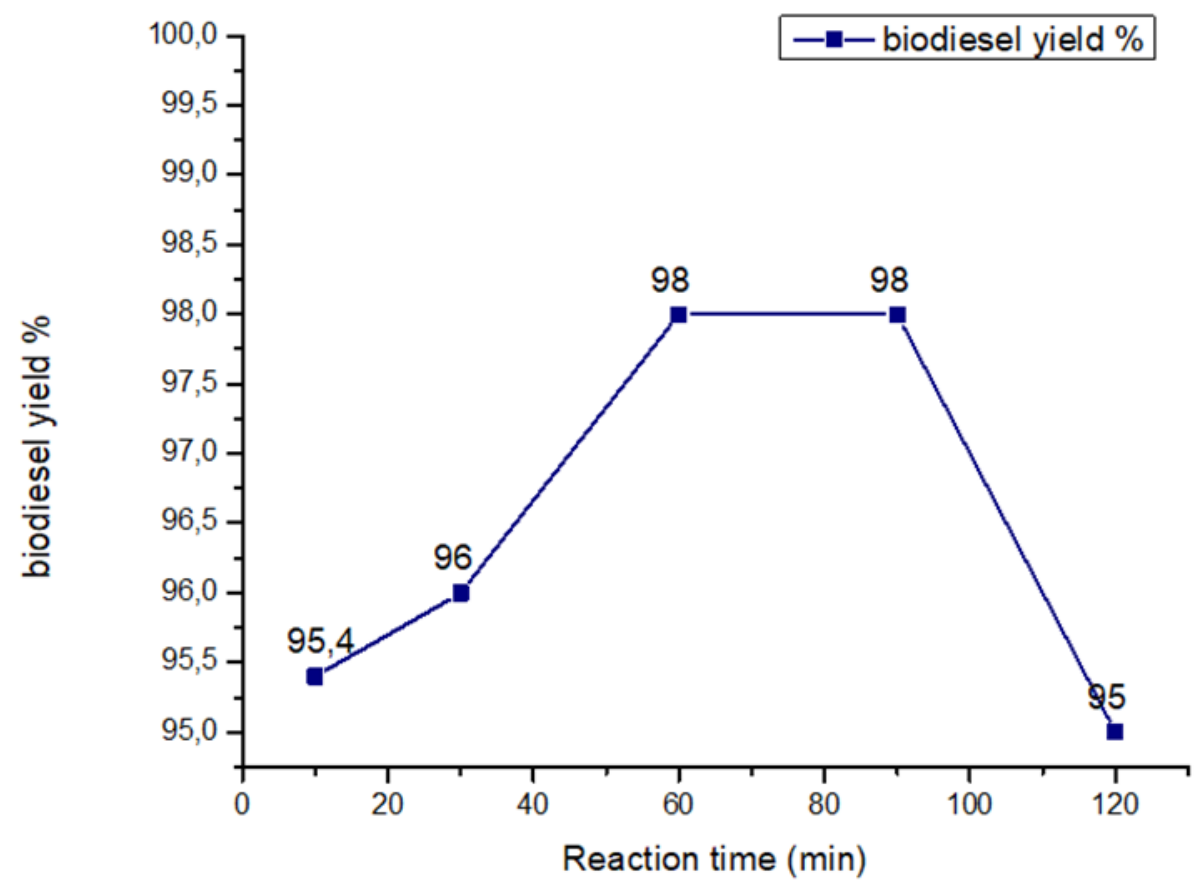

Figure 3. Evolution of biodiesel yield as a function of reaction time (KOH: $1 \%$ by weight, $\mathrm{MeOH} / \mathrm{UFO}$ molar ratio: $\left.6: 1,19^{\circ} \mathrm{C}\right)$.

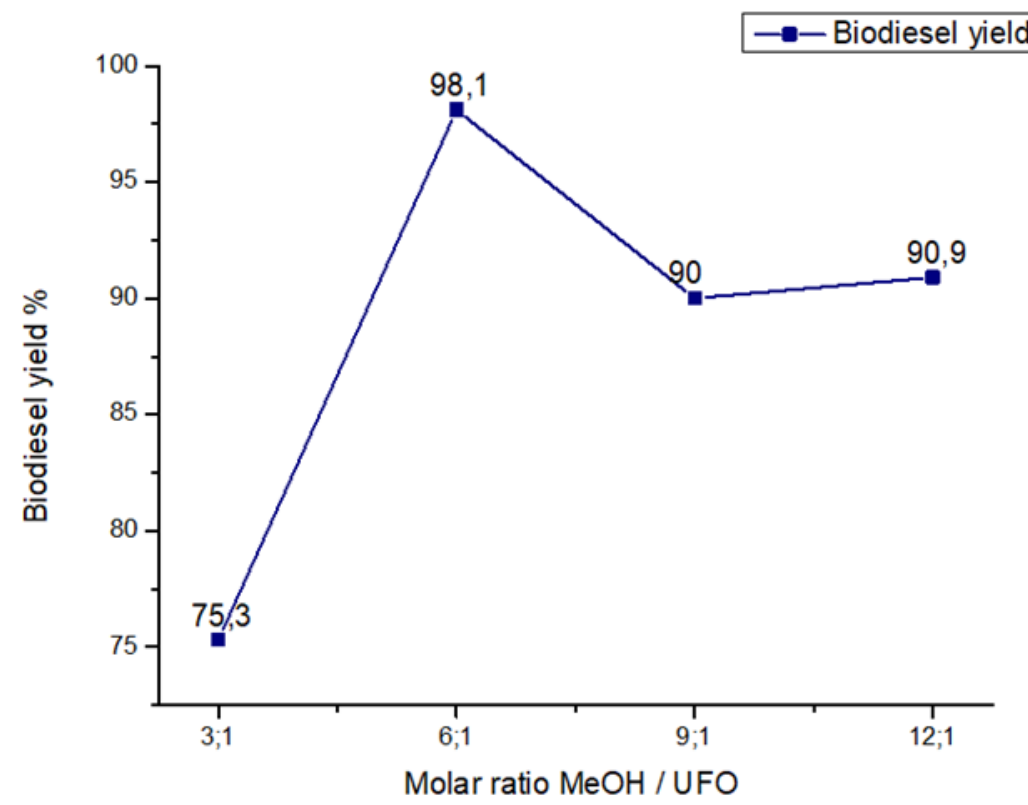

Figure 4. Evolution of the biodiesel yield as a function of the $\mathrm{MeOH} / \mathrm{UFO}$ molar ratio (KOH: $1 \%$ by weight, $60 \mathrm{~min}, 18^{\circ} \mathrm{C}$ ). 
Figure 3 shows that when the transesterification reaction is carried out at a temperature of $600^{\circ} \mathrm{C}$, biodiesel's maximum yield is obtained after $60 \mathrm{~min}$ of reaction with a percentage of $98 \%$. A yield of $95 \%$ is obtained after $10 \mathrm{~min}$ of reaction at room temperature. Therefore, the reaction time does not seem to have a great influence on the yield of biodiesel.

3.1.3. Influence of the MeOH / UFO molar ratio on the yield of biodiesel.

The study of the influence of the $\mathrm{MeOH} / \mathrm{UFO}$ molar ratio (3: 1, 6: 1, 9: 1, and 12:1) was carried out at room temperature $\left(18^{\circ} \mathrm{C}\right)$ for $60 \mathrm{~min}$ of reaction with $1 \%$ by weight of $\mathrm{KOH}$. Figure 4 shows the evolution of biodiesel yield as a function of reaction time.

The maximum biodiesel yield is of $98 \%$ corresponds to the $\mathrm{MeOH} / \mathrm{UFO}$ molar ratio of 6: 1 . The biodiesel yield is $75 \%$ for a 3: 1 ratio, $90 \%$ for a 9: 1 ratio, and $91 \%$ for a 12: 1 ratio.

The results in Figure 4 show that the $\mathrm{MeOH} /$ UFO molar ratio of 6: 1 provides the best performance from biodiesel. Subsequently, an increase in this parameter implies a decrease in the yield of the reaction.

3.1.4. Effect of the weight percentage of the catalyst ( $\mathrm{KOH}$ and $\mathrm{NaOH}) / \mathrm{UFO}$ on the yield of biodiesel.

The study of the influence of the weight percentage of the $\mathrm{KOH}$ and $\mathrm{NaOH}$ catalysts was carried out at room temperature $\left(19^{\circ} \mathrm{C}\right)$ for 60 min reaction time with a MeOH /UFO molar ratio of $6: 1$. The weight percentages, $0.5,1,1.5$, and $2 \%$ of catalyst $(\mathrm{KOH}$ and $\mathrm{NaOH})$, were tested.

Figure 5 shows the change in biodiesel yield as a function of the weight percentage of the $\mathrm{NaOH}$ and $\mathrm{KOH}$ catalyst.

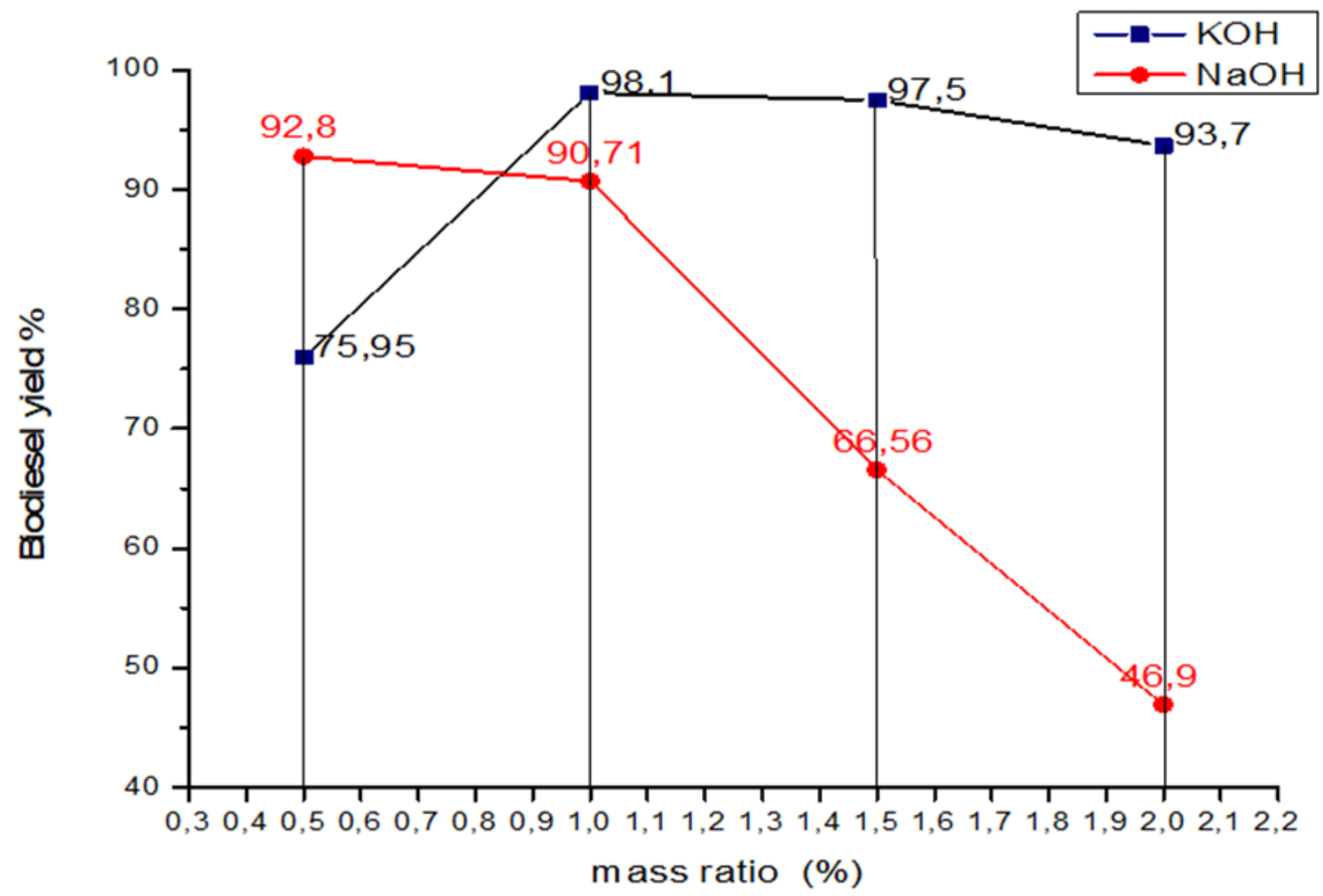

Figure 5. Evolution of biodiesel yield as a function of the percentage of $\mathrm{KOH}$ and $\mathrm{NaOH}$ catalysts $(\mathrm{MeOH}$ /UFO molar ratio: 6: $1,60 \mathrm{~min}, 19^{\circ} \mathrm{C}$ ). 
Figure 5 shows that biodiesel's maximum yield $(98.1 \%)$ corresponds to $1 \%$ mass of $\mathrm{KOH}$. The yield is $76 \%$ when using $0.5 \%$ by weight of catalyst and $97.5 \%$ for $1.5 \%$ and $93.7 \%$ by weight of $\mathrm{KOH}$ catalyst. Moreover, $\mathrm{NaOH}$ 's maximum yield reached $92.8 \%$, which corresponds to $1 \%$ by weight with a decrease in yield when the weight percentage increases caused an emulsion to form by the saponification reaction, which allows a loss of the product.

Figure 5 shows that the $1 \%$ weight percentage of $\mathrm{KOH}$ provides the best yield from biodiesel.

\subsubsection{Effect of alcohol type on the yield of biodiesel.}

The influence of alcohol type was investigated at room temperature $\left(18^{\circ} \mathrm{C}\right)$ for $60 \mathrm{~min}$ reaction time with $1 \% \mathrm{wt} ; \%$ of $\mathrm{KOH}$ and molar ratio 6: 1 with the use of methanol, ethanol, 2propanol every time. Figure 6 shows the evolution of the biodiesel yield depending on alcohol type.

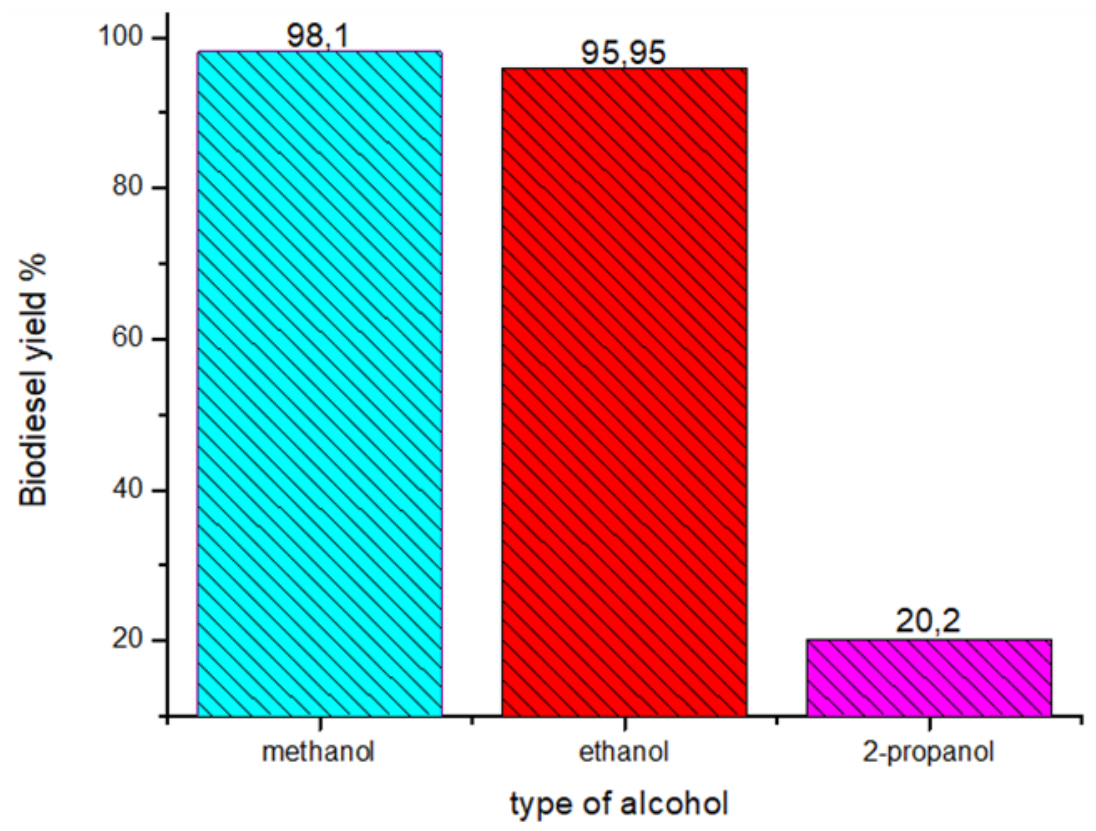

Figure 6. Evolution of biodiesel yield according to the type of alcohol (molar ratio 6: 1, $60 \mathrm{~min}, 19^{\circ} \mathrm{C}$ ).

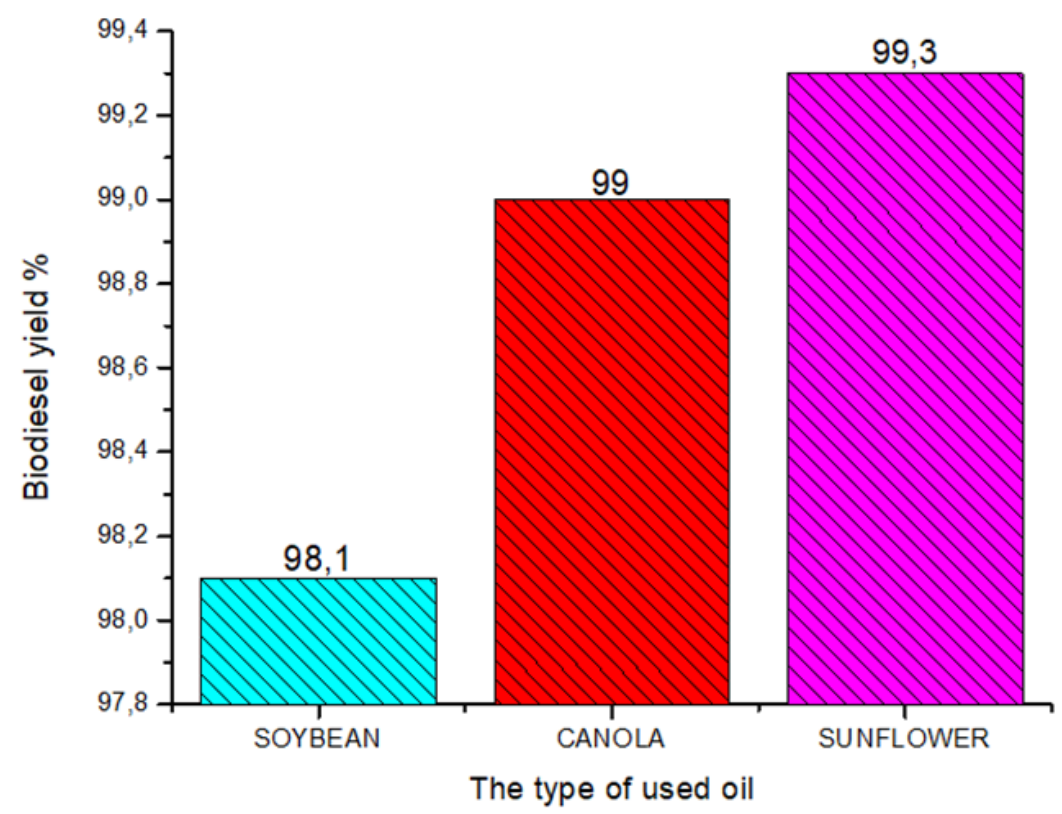

Figure 7. Evolution of the biodiesel yield according to the type of used oil (molar ratio 6: $1,60 \mathrm{~min}, 19^{\circ} \mathrm{C}$ ). 
Figure 6 shows that the maximum yield of biodiesel (98.1\%) corresponds to methanol with a slight difference between them and ethanol, but the choice should be methanol because of its low cost.

3.1.6. Effect of the type of used oil on the yield of biodiesel.

The study of the influence of the oil type was carried out at room temperature $\left(18{ }^{\circ} \mathrm{C}\right)$ for 60 min reaction time with $1 \mathrm{wt} \%$ by of $\mathrm{KOH}$, molar ratio 6: 1 and methanol using 3 used types of oils, namely Soybean, Canola, and Sunflower each time. Figure 7 shows the evolution of biodiesel yield depending on the type of used oil.

Figure 7 shows that the maximum yield of biodiesel (99.3\%) corresponds to sunflower oil with a small difference between canola and soybean, but the choice depends on the physicochemical parameters of oil, which are similar to diesel and the low cost.

The cost of sunflower and soybean is the same; on the other hand, canola's cost is 2 times greater than that of sunflower and canola.

\subsection{Physicochemical parameters of new oils (NO), used frying oil (UFO), and biodiesel.}

Table 1 shows the values of viscosities, densities, acid numbers, flash point and pour point of new oils (NO), used frying oil (UFO), biodiesel, and diesel used in this study are presented.

The transesterification reaction of NO and UFO was carried out under the conditions following procedures: reaction time: $60 \mathrm{~min}$, ambient temperature (which makes it possible to reduce the energy loss during heating), $\mathrm{MeOH} /$ oil molar ratio: 6: 1, weight percentage $\mathrm{KOH} /$ il: $1 \%$ with three types of used oils (canola, Sunflower, Soybean) that presents the optimal conditions to obtain a maximum conversion.

Due to their difference in the alkyl group, some physicochemical properties may be slightly different; it is noted that the ester's properties vary depending on the nature of the used oil.

Table 1. Physicochemical parameters of new oil (NO), used frying (UFO) and methyl ester (biodiesel) and diesel.

\begin{tabular}{|c|c|c|c|c|c|c|c|c|c|c|c|c|}
\hline & \multirow{2}{*}{ Petro-diesel } & \multirow{2}{*}{\multicolumn{2}{|c|}{$\begin{array}{c}\text { Commercial } \\
\text { biodiesel }\end{array}$}} & \multicolumn{3}{|c|}{ Soybean } & \multicolumn{3}{|c|}{ Sunflower } & \multicolumn{3}{|c|}{ Canola } \\
\hline & & & & NO & UFO & biodiesel & NO & UFO & biodiesel & NO & UFO & biodiesel \\
\hline Density (at $15^{\circ} \mathrm{C}$ ) & $0.81-0.87[48]$ & $0.86-0.9$ & [51] & 0.920 & 0.922 & 0.887 & 0.922 & 0.923 & 0.885 & 0.920 & 0.920 & 0.883 \\
\hline Viscosity $($ at $40 \mathrm{oC})(\mathrm{mm} 2 / \mathrm{s})$ & $1.5-5.8 \quad[48]$ & $3.5-5$ & [51] & 30.84 & 31.61 & 4.60 & 34.27 & 39.97 & 4.32 & 35.04 & 39.75 & 4.31 \\
\hline Acidity index (mgKOH/g) & ------ & $<0.8$ & [52] & 0.15 & 1.61 & 0.81 & 0.24 & 1.72 & 0.92 & 0.41 & 2.01 & 0.52 \\
\hline Flash point $\left({ }^{\circ} \mathrm{C}\right)$ & $60<$ & 96-190 & {$[53]$} & 326 & 320 & 159 & 308 & 321 & 186 & 310 & 314 & 172 \\
\hline Pour point $\left({ }^{\circ} \mathbf{C}\right)$ & $-35-15 \quad[50]$ & $-15+10$ & {$[54]$} & -14 & -13 & -8 & -15 & -13 & -11 & -10 & -9 & -6 \\
\hline Color & [48] & ------ & & 0.5 & 2 & 1.5 & 0.5 & 2 & 1.5 & 0.5 & 2 & 1.5 \\
\hline
\end{tabular}

In order to see if our synthesized diesel exhibit properties following those of international standards. Table 1 summarizes the comparative study results of biodiesel synthesized with petro-diesel and biodiesel according to international standards.

\subsubsection{Viscosity.}

From Table 1, it can be seen that the vegetable oil used before processing is very viscous. However, once treated by transesterification, the obtained biodiesel reveals a kinematic viscosity at $40^{\circ} \mathrm{C}$ closer to that of diesel. The viscosity decreases by of 7 to 10 order factors. This reduction is an essential advantage since it allows much better atomization 
by the injectors. Therefore much better combustion and a high kinematic viscosity would create problems such as deposits in the engine.

In fact, the required injection pressure will have to increase, which will lead to incomplete combustion, thus causing unburnt material that will clog on the nose of the injectors, the cylinders, and the pistons. This fact will also lead to the obstruction of the engine power supplies [55].

The viscosity of synthesized biodiesel varies from $4.31 \mathrm{~mm}^{2} / \mathrm{s}$ to $4.6 \mathrm{~mm}^{2} / \mathrm{s}$; it conforms to standards and is close to diesel density.

\subsubsection{The acidity index.}

The acidity index of biodiesel was determined using the same operating protocol for oils. It varies according to the used oil type, but it should not go over 0.8 to $1 \mathrm{mg} \mathrm{KOH} / \mathrm{g}$. This can also lead to corrosion problems, noting that used oils with acidity index greater than the obtained biodiesel and new oils caused the oxidation reaction during use at high temperatures (between $160^{\circ} \mathrm{C}$ and $180^{\circ} \mathrm{C}$ ), in the presence of water and oxygen, they cause the appearance of aromas and color changes in used frying oils which increases the acidity index of used oils, but when the transesterification reaction of the used oils decrease the acidity index instead, this confirms that the transesterification reaction refines the oils of these free fatty acids and also by the elimination of the glycerol which is corrosive. By comparing it with the international standard, we find that our biodiesel conforms to the standards.

\subsubsection{The flashpoint.}

The flashpoint of biodiesel is higher than that of diesel. This makes them less dangerous to handle than diesel.

\subsubsection{The pour point.}

Biodiesel has a pour point conforming to international standards close to diesel, which notably improves cold starting.

\subsubsection{Density.}

According to the results of Table 1, the density values are between 0.883 and 0.887 . Therefore, the density of all biodiesels meets the standards, and it is close to the density of diesel. The difference recorded between the density of pure oil and waste oils may be due to the use of high temperatures (between 160 and $180^{\circ} \mathrm{C}$ ) during frying. In the presence of water and oxygen, triglycerides undergo a large number of complex reactions, which can be classified into three main families: oxidation, polymerization, and hydrolysis.

It is clear that the physicochemical properties change dramatically when switching from oil to the corresponding biodiesel. The properties of diesel are then approached. Examination of Table 1 shows that our biodiesel exhibits characteristics that meet standards.

\section{Conclusions}

An optimization study was also carried out to optimize the transesterification reaction's conditions achieving the maximum yield of biodiesel. This study showed that the transesterification of used frying oils at room temperature $\left(18^{\circ} \mathrm{C}\right)$ for $60 \mathrm{~min}$ of reaction in the 
presence of methanol with a molar ratio $\mathrm{MeOH} / \mathrm{UFO}$ of 6: 1 with 1 weight percent of $\mathrm{KOH}$ gives an Optimal conversion of used frying oils (UFO) the yield is at $99.3 \%$ for UFO of Sunflower origin and $98.1 \%$ for UFO of Soybean origin. The obtained biodiesel has physicochemical characteristics comparable to those of commercial biodiesel and petrodiesel, according to international standards. According to these comparisons, we can say that the synthesized biodiesel has characteristics following the standards and very close to diesel in standing point of characteristics and of the released energy.

\section{Funding}

This research received no external funding.

\section{Acknowledgments}

The authors would like to thank the support of Mrs. Fatma Afrine for her support, the authors warmly appreciate the discussion with Dr. Seema Sudhakaran Pillai from Kingston University (UK). Many thanks to A. M. Shajib for his kind support and English revision.

\section{Conflicts of Interest}

The authors declare no conflict of interest.

\section{References}

1. Mahlia, T.M.I.; Syazmi, Z.A.H.S.; Mofijur, M.; Abas, A.P.; Bilad, M.R.; Ong, H.C.; Silitonga, A.S. Patent landscape review on biodiesel production: Technology updates. Renew. and Sustainable Energ. Rev. 2020, 118, https://doi.org/10.1016/j.rser.2019.109526.

2. Hendrawan, Y.; Maharani, N. S., Argo, B. D.; Wibisono, Y. Modeling and optimization of palm oil moisture loss as biodiesel pretreatment. E\&ES 2020, 456, https://doi.org/10.1088/1755-1315/456/1/012035.

3. Goh, B.H.H.; Ong, H.C.; Cheah, M.Y.; Chen, W.H., Yu, K.L., Mahlia, T.M.I. Sustainability of direct biodiesel synthesis from microalgae biomass: A critical review. Renew. and Sustainable Energ. Rev. 2019, 107, 59-74, https://doi.org/10.1016/j.rser.2019.02.012.

4. Zhang, Y.; Ghaly, A.E.; Li, B. Determination of the exergy of four wheat straws. Am. J. Biochem. Biotechnol. 2013, 9, 338-347, https://doi.org/10.3844/ajbbsp.2013.338.347.

5. Romprasert, S.; Jermsittiparsert, K. Energy Risk Management and Cost of Economic Production Biodiesel Project. International J. Energ. Economics and Policy 2019, 9, 349-357, https://doi.org/10.32479/ijeep.8367.

6. Chew, T.L.; Bhatia, S. Catalytic processes towards the production of biofuels in a palm oil and oil palm biomass-based biorefinery. Bioresour. Technol. 2008, 99, 7911-7922, https://doi.org/10.1016/j.biortech.2008.03.009.

7. Zhang, Y.; Zhao, W.; Li, B.; Li, H. Understanding the Sustainability of Fuel from the Viewpoint of Exergy. Eur. J. Sustain. Dev. Res. 2018, 2, https://doi.org/10.20897/ejosdr/76935.

8. Rajaeifar, M.A.; Tabatabaei, M.; Aghbashlo, M.; Nizami, A.S.; Heidrich, O. Emissions from urban bus fleets running on biodiesel blends under real-world operating conditions: Implications for designing future case studies. Renew. Sust. Energ. Rev. 2019, 111, 276-292, https://doi.org/10.1016/j.rser.2019.05.004.

9. Zhang, Y.; Ghaly, A.E.; Li, B. Comprehensive investigation into the exergy values of six rice husks. Am. J. Eng. Appl. Sci. 2013, 6, 216-225, https://doi.org/10.3844/ajeassp.2013.216.225.

10. Silitonga, A.S.; Shamsuddin, A.H.; Mahlia, T.M.I.; Milano, J.; Kusumo, F.; Siswantoro, J.; Ong, H.C. Biodiesel synthesis from Ceiba pentandra oil by microwave irradiation-assisted transesterification: ELM modeling and optimization. Renew. Energ. 2020, 146, 1278-1291, https://doi.org/10.1016/j.renene.2019.07.065.

11. Sathiyamoorthi, R.; Sankaranarayanan, G.; Chiranjeevi, T.; Kumar, D.D. Experimental investigation on performance, combustion and emission characteristics of a single cylinder diesel engine fuelled by biodiesel derived from Cymbopogon Martinii. Renew. Energ. 2019, 132, 394-415, https://doi.org/10.1016/j.renene.2018.08.001.

12. Zhang, Y.; Ghaly, A. E.; Li, B. Availability and physical properties of residues from major agricultural crops for energy conversion through thermochemical processes. Am. J. Agric. Biol. Sci. 2012, 7, 312-321, https://doi.org/10.3844/ajabssp.2012.312.321. 
13. Zhang, Y.; Yu, X.; Li, B.; Zhang, H.; Liang, J.; Li, Y. Exergy characteristics of woody biomass. Energy Sources, Part A Recovery, Utilization, and Environmental Effects 2016, 38, 2438-2446, https://doi.org/10.1080/15567036.2015.1075088

14. Elkelawy, M.; Bastawissi, H.A.E.; Esmaeil, K.K.; Radwan, A.M.; Panchal, H.; Sadasivuni, K.K.; Walvekar, R. Experimental studies on the biodiesel production parameters optimization of sunflower and soybean oil mixture and DI engine combustion, performance, and emission analysis fueled with diesel/biodiesel blends. Fuel 2019, 255, https://doi.org/10.1016/j.fuel.2019.115791.

15. Zhang, Y.; Wang, Q.; Li, B.; Li, H.; Zhao, W. Is there a general relationship between the exergy and HHV for rice residues?. Renew Energy 2018, 117, 37-45, https://doi.org/10.1016/j.renene.2017.10.022.

16. Asadi, A.; Kadijani, O.N.; Doranehgard, M.H., Bozorg, M.V., Xiong, Q.; Shadloo, M.S.; Li, L.K. Numerical study on the application of biodiesel and bioethanol in a multiple injection diesel engine. Renew. Energ. 2020, 150, 1019-1029, https://doi.org/10.1016/j.renene.2019.11.088

17. Suganya, T.; Varman, M.; Masjuki, H.H.; Renganathan, S. Macroalgae and microalgae as a potential source for commercial applications along with biofuels production: a biorefinery approach. Renew. Sust. Energ. Rev. 2016, 55, 909-941, https://doi.org/10.1016/j.rser.2015.11.026.

18. Gardy, J.; Nourafkan, E., Osatiashtiani, A.; Lee, A.F.; Wilson, K.; Hassanpour, A.; Lai, X. A core-shell $\mathrm{SO} 4 / \mathrm{Mg}-\mathrm{Al}-\mathrm{Fe} 3 \mathrm{O} 4$ catalyst for biodiesel production. Applied Catalysis B: Environmental 2019, 259, https://doi.org/10.1016/j.apcatb.2019.118093.

19. Zhang, Y.; Chen, P.; Liu, S.; Fan, L.; Zhou, N.; Min, M.; Cheng, Y.; Peng, P.; Anderson, E.; Wang, Y.; Wan, Y.; Liu, Y.; Li, B.; Ruan, R. Chapter 6-Microwave-assisted pyrolysis of biomass for bio-oil production. In: Pyrolysis. IntechOpen; London, UK 2017; pp.129-166, https://dx.doi.org/10.5772/67442.

20. Mazloom, S.; Muhammad,T .; Saqib, A.; Qing-Xiang, G.; Yao, F. Transesterification of Jojoba Oil, Sunflower Oil, Neem Oil, Rocket Seed Oil and Linseed Oil by Tin Catalysts. Biomass. Bioener. 2014, 70, 225-229, https://doi.org/10.1016/j.biombioe.2014.08.029.

21. Krawczyk, T. Biodiesel-Alternative Fuel Makes Inroads But Hurdles Remain. Inform. 1996, 7, 801-815.

22. Singh, T.S.; Verma, T.N. Biodiesel production from Momordica Charantia (L.): Extraction and engine characteristics. Energy 2019, 189, https://doi.org/10.1016/j.energy.2019.116198.

23. Mamat, R.; Sani, M.S.M.; Sudhakar, K.; Kadarohman, A.; Sardjono, R.E. An overview of Higher alcohol and biodiesel as alternative fuels in engines. Energ. Reports 2019, 5, 467-479, https://doi.org/10.1016/j.egyr.2019.04.009.

24. Alaswad, A.; Dassisti, M.; Prescott, T.; Olabi, A.G. Technologies and developments of third generation biofuel production. Renew. Sust. Energ. Rev. 2015, 51, 1446-1460, https://doi.org/10.1016/j.rser.2015.07.058.

25. Sharma, T.; Dasgupta, D.; Singh, J.; Bhaskar, T.; Ghosh, D. Yeast lipid-based biofuels and oleochemicals from lignocellulosic biomass: life cycle impact assessment. Sustainable Energ. Fuels 2020, 4, 387-398, https://dx.doi.org/10.1039/C9SE00540D.

26. Branco-Vieira, M.; Costa, D.; Mata, T.M.; Martins, A.A.; Freitas, M.A.V.; Caetano, N.S. A life cycle inventory of microalgae-based biofuels production in an industrial plant concept. Energ. Reports 2020, 6, 397-402, https://doi.org/10.1016/j.egyr.2019.08.079.

27. Du, C.; Zhao, X.; Liu, D.; Lin, C.S.K.; Wilson, K.; Luque, R.; Clark, J. Chapter 1-Introduction: an overview of biofuels and production technologies. In: Handbook of Biofuels Production. second ed., Elsevier: Duxford, UK, 2016; pp. 3-12, https://doi.org/10.1016/B978-0-08-100455-5.00001-1.

28. Garcia, I.L. Chapter 5-Feedstocks and challenges to biofuel development. In: Handbook of Biofuels ProducItion. second ed., Elsevier: Duxford, United Kingdom, 2016; pp. 85-118, https://doi.org/10.1016/B978-0-08-100455-5.00005-9.

29. Simikic, M.; Tomic, M.; Savin, L.; Micic, R.; Ivanisevic, I.; Ivanisevic, M. Influence of biodiesel on the performances of farm tractors: Experimental testing in stationary and non-stationary conditions. Renew. Energ. 2018, 121, 677-687, https://doi.org/10.1016/j.renene.2018.01.069.

30. Jahirul, M.I.; Rasul, M.G.; Brown, R.J.; Senadeera, W., Hosen, M.A.; Haque, R., Mahlia, T.M.I. Investigation of correlation between chemical composition and properties of biodiesel using principal component analysis (PCA) and artificial neural network (ANN). Renew. Energ. 2020, 168, 632-646, https://doi.org/10.1016/j.renene.2020.12.078.

31. Rounce, P.; Tsolakis, A.; York, A.P.E. Speciation of particulate matter and hydrocarbon emissions from biodiesel combustion and its reduction by aftertreatment. Fuel 2012, 96, 90-99, https://doi.org/10.1016/j.fuel.2011.12.071.

32. Chandran, D. Compatibility of diesel engine materials with biodiesel fuel. Renew. Energy 2020, 147, 89-99, https://doi.org/10.1016/j.renene.2019.08.040.

33. Ahmad, T.; Danish, M., Kale, P.; Geremew, B.; Adeloju, S. B.; Nizami, M.; Ayoub, M. Optimization of process variables for biodiesel production by transesterification of flaxseed oil and produced biodiesel characterizations. Renew. Energ. 2019, 139, 1272-1280, https://doi.org/10.1016/j.renene.2019.03.036.

34. Nikiema, J.; Heitz, M. Biodiesel. II. Production - A Synthesis. Canad. J. Civil Engineer 2008, 35, 107-117, https://doi.org/10.1139/L07-122. 
35. Helwani, Z.; Othman, M.R.; Aziz, N.; Fernando, W.J.N.; Kim, J. Technologies for Production of Biodiesel Focusing on Green Catalytic Techniques: A Review. J. Fuel Process. Techno 2009, 90, 1502-1514, https://doi.org/10.1016/j.fuproc.2009.07.016.

36. Bastawissi, H.A.E.; Elkelawy, M.; Panchal, H.; Sadasivuni, K.K. Optimization of the multi-carburant dose as an energy source for the application of the HCCI engine. Fuel 2019, 253, 15-24, https://doi.org/10.1016/j.fuel.2019.04.167.

37. El Shenawy, E.A.; Elkelawy, M., Bastawissi, H.A.E.; Panchal, H.; Shams, M.M. Comparative study of the combustion, performance, and emission characteristics of a direct injection diesel engine with a partially premixed lean charge compression ignition diesel engines. Fuel 2019, 249, 277-285, https://doi.org/10.1016/j.fuel.2019.03.073.

38. Leung, D.Y.; Wu, X.; Leung, M.K.H. A Review on Biodiesel Production Using Catalyzed Transesterification. Appli. Energ. 2010, 87, 1083-1095, https://doi.org/10.1016/j.apenergy.2009.10.006.

39. Va Mofijur, M.; Siddiki, S.Y.A.; Ahmed, M.B.; Djavanroodi, F.; Fattah, I.R.; Ong, H.C.; Mahlia, T.M.I. Effect of nanocatalysts on the transesterification reaction of first, second and third generation biodiesel sources-A mini-review. Chemosphere 2020, https://doi.org/10.1016/j.chemosphere.2020.128642.

40. Maddikeri, G.L.; Pandit, A.B.; Gogate, P.R. Intensification approaches for biodiesel synthesis from waste cooking oil: a review. Industrial \& Engineering Chemistry Research 2012, 51, 14610-14628, https://doi.org/10.1021/ie301675j.

41. Bettahar Badoei-dalfard, A.; Malekabadi, S.; Karami, Z.; Sargazi, G. Magnetic cross-linked enzyme aggregates of Km12 lipase: A stable nanobiocatalyst for biodiesel synthesis from waste cooking oil. Renewable Energy 2019, 141, 874-882, https://doi.org/10.1016/j.renene.2019.04.061.

42. Boulal Le-Phuc, N.; Tran, T.V.; Phan, T.T.; Ngo, P.T.; Ha, Q.L.; Luong, T.N.; Phan, T.T. High-efficient production of biofuels using spent fluid catalytic cracking (FCC) catalysts and high acid value waste cooking oils. Renew. Energ. 2021, 168, 57-63, https://doi.org/10.1016/j.renene.2020.12.050.

43. Fonseca, J.M.; Teleken, J.G.; de Cinque Almeida, V.; da Silva, C. Biodiesel from waste frying oils: Methods of production and purification. Energy Convers. Manag 2019, 184, 205-218, https://doi.org/10.1016/j.enconman.2019.01.061.

44. Fawaz, E.G.; Salam, D.A. Preliminary economic assessment of the use of waste frying oils for biodiesel production in Beirut, Lebanon. Sci. of The Total Environment 2018, 637, 1230-1240, https://doi.org/10.1016/j.scitotenv.2018.04.421.

45. Kolhe, N.S.; Gupta, A.R.; Rathod, V.K. Production and purification of biodiesel produced from used frying oil using hydrodynamic cavitation. Resource-Efficient Technologies 2017, 3, 198-203, https://doi.org/10.1016/j.reffit.2017.04.008.

46. Vastano, M.; Corrado, I.; Sannia, G.; Solaiman, D.K.; Pezzella, C. Conversion of no/low value waste frying oils into biodiesel and polyhydroxyalkanoates. Sci. Reports 2019, 9, 1-8, https://doi.org/10.1038/s41598019-50278-x.

47. Patchimpet, J.; Simpson, B.K.; Sangkharak, K.; Klomklao, S. Optimization of process variables for the production of biodiesel by transesterification of used cooking oil using lipase from Nile tilapia viscera. Renew. Energ. 2020, 153, 861-869, https://doi.org/10.1016/j.renene.2020.02.039.

48. Na, M.M.; Abd Aziz, A.R.; Hagos, F.Y.; Noor, M.M.; Kadirgama, K.; Mamat, R.; Abdullah, A.A. The influence of formulation ratio and emulsifying settings on tri-fuel (Diesel-Ethanol-Biodiesel) emulsion properties. Energies 2019, 12, https://doi.org/10.3390/en12091708.

49. Tan, Y.H.; Abdullah, M.O.; Nolasco-Hipolito, C.; Zauzi, N.S.A.; Abdullah, G.W. Engine performance and emissions characteristics of a diesel engine fueled with diesel-biodiesel-bioethanol emulsions. Energ. Conversion and Management 2017, 132, 54-64, https://doi.org/10.1016/j.enconman.2016.11.013.

50. National Alleman, T.L.; McCormick, R.L.; Christensen, E.D.; Fioroni, G.; Moriarty, K.; Yanowitz, J. Biodiesel handling and use guide (No. NREL/BK-5400-66521; DOE/GO-102016-4875). Golden, CO (United States). Nat. Renew. Energ. Lab. 2016.

51. Aydın, F.; Öğüt, H. Effects of using ethanol-biodiesel-diesel fuel in single cylinder diesel engine to engine performance and emissions. Renewable Energy 2017, 103, 688-694, https://doi.org/10.1016/j.renene.2016.10.083.

52. Fernando, S.; Karra, P.; Hernandez, R.; Jha, S.K. Effect of incompletely converted soybean oil on biodiesel quality. Energ. 2007, 32, 844-851, https://doi.org/10.1016/j.energy.2006.06.019.

53. Srivastava, A.; Prasad, R. Triglycerides-based diesel fuels, Renew. and Sustainable Energ. Rev. 2000, 4 , 111-133, https://doi.org/10.1016/S1364-0321(99)00013-1.

54. Lapuerta, M.; Armas, O.; Rodriguez-Fernandez, J. Effect of biodiesel fuels on diesel engine emissions, Prog. Energy Combust. Sci. 2008, 34, 198-223, https://doi.org/10.1016/j.pecs.2007.07.001.

55. Abolle, A.; Kouakou, L.; Planche, H. The viscosity of diesel oil and mixtures with straight vegetable oils: Palm, cabbage palm, cotton, groundnut, copra and sunflower. Biomass and Bioenerg. 2009, 33, 1116-1121, https://doi.org/10.1016/j.biombioe.2008.01.012. 